\title{
Reuna
}

\section{EVALUATION OF THE BUSINESS ENVIRONMENT FOR USE OF INFORMATION IN THE DEFINITION OF BUSINESS STRATEGIES}

\section{AVALIAÇÃO DO AMBIENTE DE NEGÓCIOS PARA USO DE INFORMAÇÕES NA DEFINIÇÃO DE ESTRATÉGIAS EMPRESARIAIS}

http://dx.doi.org/10.21714/2179-8834/2018v23n3p32-53

\author{
Frederico Cesar Mafra Pereira \\ FPL Educacional (Fundação Pedro Leopoldo), Brasil. \\ E-mail: professorfrederico@yahoo.com.br
}

Submissão: 05 Dez. 2017 Publicação: 25 Fev. 2019. Sistema de avaliação: Double blind review. Centro Universitário UNA, Belo Horizonte - MG, Brasil. Editor geral: Prof. Dr. Gustavo Quiroga Souki

Este artigo encontra-se disponível nos seguintes endereços eletrônicos:

http://revistas.una.br/index.php/reuna/article/view/1000

http://dx.doi.org/10.21714/2179-8834/2018v23n3p32-53

\begin{abstract}
Accompanying and interpreting the business environment is challenging for contemporary organizations, requiring greater agility and assertiveness to access and interpret data, generate information, share knowledge and make decisions. In this context, the main objective of this study was to evaluate, based on a descriptivequantitative research, the perception of entrepreneurs and managers of micro, small, medium and large companies located in Belo Horizonte (MG), about the importance degree and the rate of change of the sectors/components of their business environment, and the main uses given to the information collected in such environment. The results allowed to identify the importance degree that the interviewees give to the constituent sectors of their respective business environments, as well as the perception they have about the rate of change in these sectors, especially in the Clients, Economic and Technology and Innovation sectors. It was possible to identify the main uses given to the information coming from their business environments, highlighting the information search in order to assist the decision-making processes. In addition to these contributions, it was possible to test the theoretical analytical model proposed and used as a framework for the elaboration of the collection instrument and for the analysis of the collected data.
\end{abstract}

Keywords: Business Environment; Market Monitoring; Competitive Intelligence; Information Use; Business Strategies. 


\section{RESUMO}

Acompanhar e interpretar o ambiente de negócios é desafiante para as organizações contemporâneas, exigindo maior agilidade e assertividade para acessar e interpretar dados, gerar informações, compartilhar conhecimentos e tomar decisões. Diante deste contexto, o presente trabalho teve como principal objetivo, a partir de uma pesquisa do tipo descritivo-quantitativa, avaliar a percepção dos empresários e gestores de micro, pequenas, médias e grandes empresas, localizadas em Belo Horizonte (MG), sobre o grau de importância e a taxa de mudança dos setores/componentes do seu ambiente de negócios, e os principais usos dados às informações coletadas neste ambiente. Os resultados permitiram identificar o grau de importância que os entrevistados dão aos setores constituintes dos seus respectivos ambientes de negócios, bem como a percepção que possuem quanto à taxa de mudança destes setores, com destaque para os setores Clientes, Econômico e Tecnologia e Inovação. Foi possível identificar os principais usos dados às informações advindas dos seus ambientes de negócios, com destaque para a busca de informações com vistas a auxiliar os processos de tomada de decisão. Além destas contribuições, foi possível testar o modelo teórico analítico proposto e utilizado como estrutura para elaboração do instrumento de coleta e para a análise dos dados coletados.

Palavras-chave: Ambiente de Negócios; Monitoramento de Mercado; Inteligência Competitiva; Uso da Informação; Estratégias Empresariais.

\section{Introduction}

Monitor and interpret the complex business environment is a challenge to the contemporary organizations that, not to be buried by thousands of information daily, need to know access them, take ownership of these and use them, as well as ensure the retention and dissemination of acquired knowledge (Choo, 2006). This context requires, of the companies and their professionals, greater agility, assertiveness to access and interpret data, generate information, share knowledge and make decisions. In this sense, several authors emphasize the relevance of the information and knowledge in the organizational sphere as a source of sustainable competitive advantage (Davenport and Prusak, 1998; Nonaka and Takeuchi, 2008; Mafra Pereira and Santos, 2015; Oliveira and Sade, 2016). However, Wilson (1997) had already warned about the informational processes in companies, often unclear, poorly demarcated, complex and composed of many subjective aspects, this scenario still needs to be improved.

Whereas the organizations are designed as open systems which maintain continuous interaction with their environments (Katz \& Kahn, 1978), the ways in which this interaction occurs is an important research question not only for scholars of organizations, but also for those interested in the informational flows that enable this interaction. For this reason, market monitoring practices and/or Competitive Intelligence (Valentim and Cervantes, 2003) may allow organizations to obtain information about their business environment, with a view to its use and the definition of business strategies in favor of the pursuit of survival, differentiation and greater competitiveness in the market (Santos, Alves and Almeida, 2007; Filardi, Santos, 
Oliva, Grisi and Lima, 2012; Roman, Piana, Pereira, Lozano and Erdmann, 2012; Schreiber, Bessi, Puffal and Tondolo, 2013; Oliveira and Teles, 2015; Mafra Pereira, Jeunon, Barbosa and Duarte, 2018).

This work was conducted with the main objective to evaluate the perception of entrepreneurs and business managers of micro, small, medium and large sizes, located in Belo Horizonte (MG), on the degree of importance and the rate of change of the sectors/components of their business environment, and the main uses given to the information collected in this environment. In specific terms, it was tried to study: (i) the degree of importance of sectors/components of the business environment of the target enterprises; (ii) the rate of change of the sectors/components of the business environment of the target enterprises; (iii) the main uses data to information gathered in the business environment of the target enterprises.

This article is organized into five chapters. In addition to this introduction, including a brief contextualization and respective goals and justifications, a theoretical foundation is presented in the second chapter, with the focus of framing the issue of research under the theoretical point of view. In the third chapter the methodological procedures used are presented, followed, in chapter four, the presentation of results and their analysis and discussions (arranged according to the specific objectives of research in confrontation with the theoretical basis studied). Conclusively, the final considerations of the study in chapter five are presented, with the main fruits and the limitations of the research, as well as the possible contributions of academic and practical background.

\section{Theoretical Foundation}

Monitor the business environment, preferably intelligently, enables companies to collect and use the information in support of their business strategies. In this sense, the reference that allows to underpin this research from the theoretical point of view, enabling its solid construction and reasoned, discusses the business environment and its external components, the monitoring of market and competitive intelligence, as well as the use of information from the external environment aiming at the development of business strategies.

\subsection{The Business Environment and its external components}

According to Oliveira (2003, pages 55 and 92), the business environment of an organization is marked "not as a stable, uniform and disciplined set, but quite dynamic in which it operates a large amount of forces, of different sizes and natures, in different directions, and which changes each time, because each one of these forces interfere with, influence and interact with the other forces of the environment". Duncan (1972) calls the business environment as the organizational environment, while Fremont (1980) classifies in general and task environment. In practice, the business environment is the set of all external factors which have an influence on a system (in this case, an organization), and is formed by two dimensions: The Macro environment and the business sector. 
Figure 1 - General model of strategic decision making.

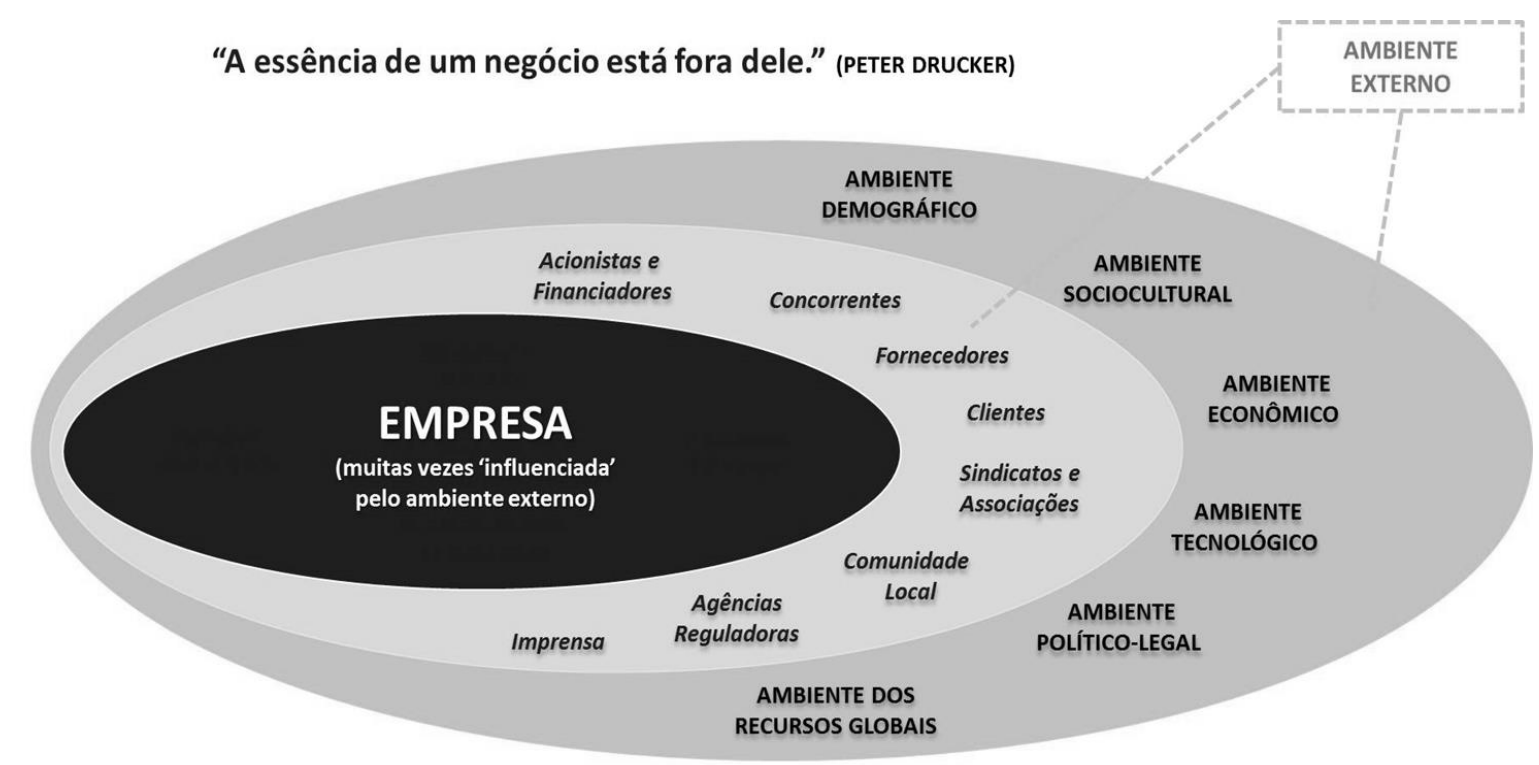

Source: Prepared by the author (2017).

Barbosa (1997; 2002) have already highlighted several important authors in the field of the theory of organizations that share these perspectives, as Dill (1958), Burns and Stalker (1961), Cyert and March (1963), Lawrence and Lorsch (1967), Katz and Kahn (1978), Aldrich (1979) and Degent (1986). With respect to the business sector, Dill (1958) categorized it as the task environment, formed by various actors, such as: customers (distributors and users), suppliers, competitors (by markets and resources) and regulatory groups (government, trade unions, inter organizational associations). For Katz and Kahn (1978), companies were considered open systems in continuous interaction with their environments and their factors (including several levels), such as: social values, political aspects, economic aspects and informational and technological aspects. Whereas Degent (1986) categorized the external organizational environment in industries such as: customers, competitors, technology, governmental policies, geopolitical situation and socioeconomic factors, also without differentiating levels of this organizational environment (macro environment or general environment, business sector or job environment).

For Aldrich (1979), the business environment of organizations could be seen as a source of resources and source of information. In the latter case, the vision of organizations as entities processors of information was essential for the completion of studies on the processes by which they adapt to their business environments, and about the forms of collection, systematization, storage and use of information in order to ensure their survival and development, especially in complex and unstable environments (Barbosa, 1997; 2002). Considering these latest features increasingly present in business environments of contemporary organizations, it is realized the growing importance and, therefore, the challenge for part of their managers and executives, accompanying the multiplicity of aspects relating to this context and identify their implications for the business. Furthermore, as pointed by Barbosa $(2002 ; 2006)$, the set of elements or components of the external environment tends to change each 
time more quickly, increasing every day, the degree of complexity and the speed which it is changed.

However, what one observes, empirically and through studies of more scientific and academic character, is that administrators, regardless of the size of their companies, tend to accompany such dynamism of their business environment, in their majority, in an informal way and reactive, i.e., little structured, formalized and proactive.

Regarding the various proposals for the classification of the components of the business environment, this study will be adopted a categorization based on Daft, Sormune and Parks (1988), Auster and Choo (1994), Barbosa (2002) and Mafra Pereira (2006), through which the business environment is subdivided into six sectors or segments:

1. Sector Customers: refers to companies or individuals who purchase the products or services of the organization;

2. Competition sector: covers all companies with which the organization in question competes in the market;

3. Technology and Innovation Sector: consists of trends concerning the development of new products and processes, innovations in information technology, scientific and technological trends, etc.;

4. Political-Regulatory Sector: involves laws and regulations at national, regional or local level and political developments in the various levels of government;

5. Economic sector: includes factors relating to the capital market, stock market, inflation rates, results of the trade balance, public sector budgets, interest rates, rates of economic growth, among others;

6. Sociocultural and demographic sector: covers aspects such as the population values, ethics on the job, demographic trends, etc.

According to Rocha Junior, Guimarães and Jeunon (2014), obtaining information relevant to business requires competence on the part of organizations and their professionals. To Albano and Araújo (2013), through managerial systematized practices, it becomes possible to use, strategically, the numerous information from the external environment to outline actions that can provide not only to survival, but also the growth of the company, seeking synergy with the competitive market and elements for the decision-making process (Barbalho, Valentim and Hoffmann, 2007). In this context, Silva (2012) points out the practices relating to the monitoring of market and competitive intelligence as of fundamental importance for such purposes.

\subsection{From the Market Monitoring to the Competitive Intelligence}

The market monitoring, although seems a complex activity and restricted to large companies, is likely to be carried out by organizations of any size. To Barbosa (2008), the difference consists of the structure available for the implementation of the market analysis. Martins (2011), for example, highlights that, in small businesses, the monitoring of the market can concentrate on analysis of aspects related to the strategy, directing their efforts for the implementation of Competitive Intelligence. 
Hoffman (2011, page 5) says that "the monitoring works as a radar, oriented to detect and interpret the signals relating to the organization, including a quantity of personal and organizational activities", and that the organization committed to maintain the monitoring of the market can gain advantages in relation to the competitors. This process has been studied by several researchers, who, in their majority, adopt the precursor definition of Aguilar (1967, page 1): "search for information about events and relationships in the external environment of a company, knowledge which will assist the main executives in the task of defining the company's future line of action". Many other concepts are associated with monitoring, as competitor intelligence, competitive intelligence, business intelligence, social intelligence management, strategic issues (issues management), information for business, technological forecasting, scenario building and organizational competitive intelligence, among others, being that, in many contexts, these concepts are considered equivalent (Barbosa, 1997; Canongia, Lamb, Carvalho and Valdenis, 2001; Teixeira and Valentine, 2016).

The Competitive Intelligence $(\mathrm{Cl})$ presents itself as an innovative practice and generating knowledge to the decision makers, according to Buzzerio and Marcondes (2014). Gomes and Braga (2004) already pointed out that the application of HF in organizations was not recent, settling as from the end of the decade of 1980, from methods and practices dispersed, but evolving to a formal process and more strategic, directly aligned with the decision-making process of the organizations. Tyson (1990) already defined $\mathrm{Cl}$ as the discipline capable of integrating the strategic planning and marketing activities and information, aiming the constant monitoring of the external environment, with fast and accurate responses to the company, in respect to the movements of the market. At this point, the multidisciplinary character of $\mathrm{JC}$ is emphasized, which involves contributions from the areas of Strategy, Marketing, decision-making, Information Science and Computing Science (Mafra Pereira, Carvalho and Jordão, 2016).

Lodi (2006) pointed out that, much more than monitoring the movements of competitors and evaluating their resources and capabilities, IC is in charge of the competitive environment as a whole to anticipate changes in the macro level (political, economic, social, technological, environmental, legal or regulatory) and the level of market behavior of consumers and of competitors, mergers, acquisitions and dynamics of innovation).

Miller (2002, page 45) emphasized that, on the basis of multiple factors to which organizations are susceptible, IC has been transformed into a 'potentiating instrument' for making decisions, being possible to identify scenarios that "foreshadow events that will bring implications strategies for the competitive positioning of the company". For Gomes and Braga (2004), "intelligence is the information that enables the executive to take a decision because it provides a degree of prediction of things that might cause impact to the organization." To Teixeira (2007), the intelligence takes two meanings, taking the strategic intelligence (EI) focus on decision-making oriented to the future and in reducing the risks of the company, and the tactical intelligence (IT) focus on the present, providing information for the monitoring of the organizational environment in "real time". For this author, HF, regardless of being tactical or strategic, includes specific information about the market and competition, and requires reading of necessity and priority of actions, sometimes in the short term (IT), sometimes in the long-term (IE). 
Bortoluzzi, Da Silva, Saciloto and Fachinelli (2014, p.32) defines the $\mathrm{Cl}$ as the "process to increase the competitive advantage of a company, with the intelligent use of information available to decision-making". To Mafra Pereira, and Santos (2015), the IC enhances the competitiveness of the organization on the market when selecting the information that is relevant to the business (Herring, 1999; 2005), assisting the owner in the wise management of the enterprise. And to Mafra Pereira, Carvalho and Jordão (2016), IC enables the continuing construction of scenarios through signs that predict potential changes in the business environment of the organization, being possible to plan and readequate the company to face challenges of the environment in which it is inserted.

\subsection{Purposes of information use of the Business Environment}

To Choo (2006), the use of the information in the business context, must always be related to a particular purpose or goal, i.e., to be turned to the action. And according to this author, the research on organizational theory shows that businesses create and use the information in three strategic 'arenas'. In the first - Formation of sense making, the organization uses the information to give meaning to the changes in its business environment, developing the perception of the influence of this environment in its daily activity, allowing the same to gain competitive advantage in relation to the competitors, for example. In the second arena - creation of knowledge through the process of organizational learning, the information is used to create new knowledge, combining the expertise of the various members of the organization, with the aim of learning and to create conditions favorable to the innovative process. In the third arena - strategic decision-making, the organization processes and analyzes the information, which is used as a subsidy to choose courses of action appropriate to its business (or as a subsidy to the decision-making process). These three arenas of strategic use of information, according to Choo (2006), are, in practice, e interlinked and interdependent processes, and their analysis is in what he called "holistic vision of the use of information", characterizing what was called 'Organization of Knowledge'. 
Figure 2 - The organization of knowledge.

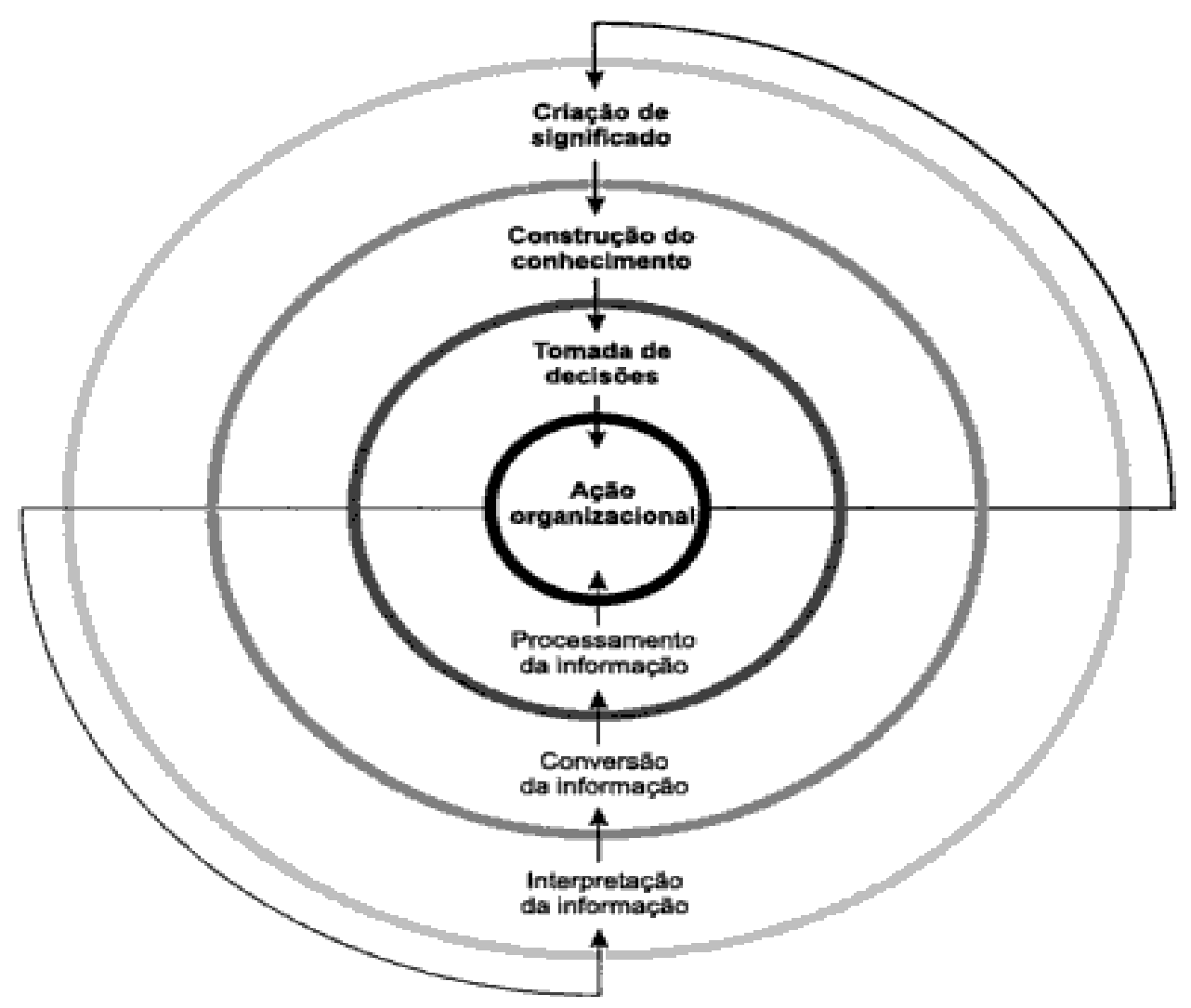

Source: Choo (2006).

The use of information is transformed into organizational action, which, in practice, represents the business strategy that the company should follow (Mintzberg, 2007) to generate superior value to competitors and differentiate themselves in the marketplace. For business strategy it means the "set of rules of decision-making for the guidance of the behavior of an organization" (Ansoff and McDonell, 1993, page 47). Harrison (2002, page 26) highlights that the corporate strategy needs to contemplate the business environment, to "move the organization and implement the strategies, all in an effort to meet its main stakeholders". That is, the better the set of assumptions and hypotheses that the company can gather, from the systematic monitoring of the market and/or its process of IC, the greater will be the chances of achieving the desired competitive advantage (Mintzberg, 1987; Porter, 1996; Barney and Hesterly, 2007). 


\subsection{Theoretical milestone: proposition of a theoretical model of analysis}

Based on the theoretical framework presented, the proposition is reached of a theoretical model of analysis (Figure 3), which formed the basis of the research now held.

Figure 3 - Analytical Theoretical Model: Information for use and definition of business strategies via monitoring of the Business Environment and Competitive Intelligence.

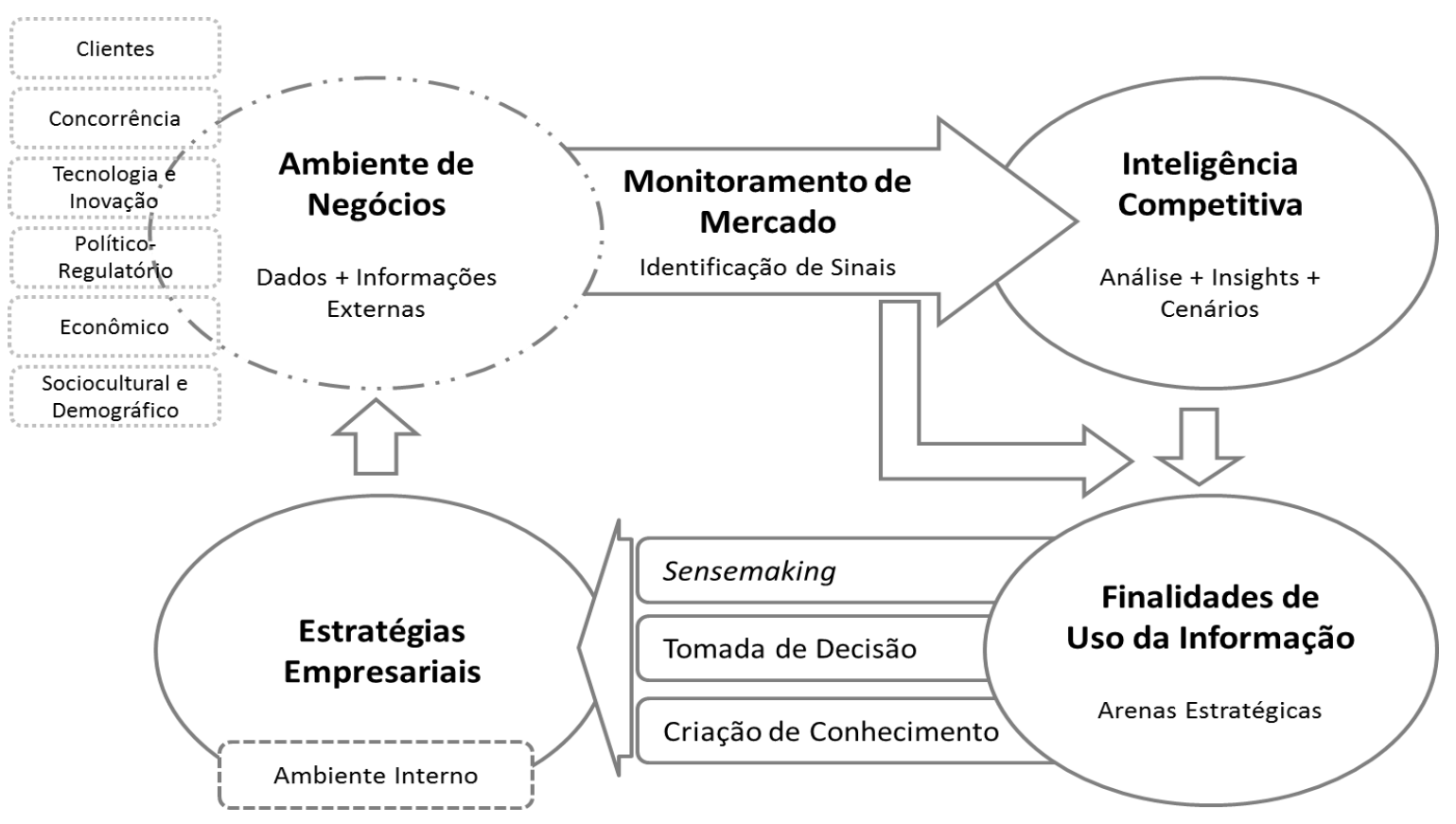

Source: Prepared by the author (2017).

The Business Environment contains data and information about facts and events relating to their sectors/components, and which may have an impact on the competitiveness of the company. This, in turn, can identify signs (positive and/or negative) arising out of your business environment, from monitoring activities of the market. Such activities, when structured, allow the company to define a process of Competitive Intelligence, with focus on the analysis of the signals monitored and generation of insights and scenarios of future action. Both processes - Monitoring of market and/or Competitive Intelligence - provide company information interpreted and/or analyzed for its use, in accordance with its purposes ('strategic arenas'). That is, the company may use the information to understand the dynamics of their business environment, to create new organizational knowledge or for decision-making. Whatever the intended uses of the information, they will allow the company to define their business strategies, which can be directed to both its internal environment, in order to leverage strengths or weaknesses, as to fix its business environment, through actions for improvement of its positioning and competitiveness in the market. And therefore, the phases of the model are repeated, characterizing a virtuous cycle of acquisition, generation, interpretation, analysis, dissemination and use of information by companies, in its environment. 


\section{Methodological procedures}

The methodology used in this study was divided into two distinct and subsequent stages. At first, literature research was performed (Samara and Barros, 2002) for mapping and identification of the categories to be used in the theoretical analytical model. In a second moment, quantitavive-descriptive research was conducted (Creswell, 1994) with the main objective to evaluate the perception of entrepreneurs and business managers of micro, small, medium and large sizes, located in Belo Horizonte (MG), on the degree of importance and the rate of change of the sectors/components of their business environment, and the main uses given to the information collected in this environment.

It was used for data collection a structured questionnaire of quantitative type non-disguised (Cervo, Bervian and Da Silva, 2009), already pre-tested and validated in studies of Mafra Pereira (2006), Mafra Pereira and Barbosa (2009) and Mafra Pereira (2016), applied to a sample of the type non-probabilistic intentional for accessibility (Malhotra, 2001; Samara and Barros, 2002), totaling 131 respondents (60 representatives of micro, small and medium-sized enterprises, and 71 large companies). In the first part of the questionnaire, each sector/component of business environment was evaluated in terms of their degree of importance and their rate of change, from the perception of the respondents, through a Likert scale of 5 points (Silva and Costa, 2014). For the degree of importance, the scale used included the following points: 'without importance', little Important', 'Important', 'very important' and 'extremely important'. For the degree of change, the scale used included the following points: 'Very low', 'low', 'average', 'high' and 'very high'. In the second part of the questionnaire, the main uses were identified given to information gathered in the business environment of each company, taking as a basis the three arenas strategies of information use of Choo (2006).

Entrepreneurs and managers were selected from master's degree courses in Administration and Graduate Program in strategic management of three educational institutions acting in the market of Minas Gerais, in which the researcher acts as a professor. The interviews were carried out in the period from November 2016 to April 2017, through the application of the questionnaires in the classroom. The questionnaires were tabulated and processed using the statistical software IBM SPSS Statistics 20, and the data were analyzed by descriptive statistical technique basic (Pinheiro, Da Cunha, Carvajal and Gomes, 2009).

\section{Presentation, analysis and discussion of the Results}

The 131 interviews were divided as follows: $16 \%$ belong to micro businesses (from 1 to 9 people), $19 \%$ to small businesses (from 10 to 49 people), $11 \%$ to mediumsized enterprises (from 50 to 99 people), and 54\% to large companies (100 people or more), according to the classification criteria adopted by the Brazilian Micro and Small Business Support Service (Sebrae, 2015). In addition, the participating companies represent all sectors of the economy mining/Brazilian agribusiness, industry, commerce and services). 
Therefore, in this study, it was opted to aggregate the micro, small and mediumsized enterprises, denominating them small and medium sized businesses (EPMP), and compare the data with those obtained from large companies (GE). This choice allowed to leave more explicit differences in perceptions between entrepreneurs and managers interviewed by size of companies, since not only the characteristics, but mainly the processes of market monitoring, $\mathrm{Cl}$, purposes of use of information and definition of business strategies, tend to be different among the companies of these groups, as already been pointed out in studies in the literature on EPMP administration versus GE.

\subsection{Perception regarding the degree of importance of sectors of the business environment}

Table 1 presents the perception of owners and/or managers of groups of EPMP and GE when the degree of importance of the constituent sectors of their business environments, with emphasis on the sum percentage of the conditions 'extremely important' and 'very important', on the one hand, and 'little important' and 'without importance', on the other hand.

Table 1 - Degree of importance - Sectors of the Business Environment

\begin{tabular}{l|c|c|c|c|c|c}
\hline \multirow{2}{*}{$\begin{array}{c}\text { Sectors of the } \\
\begin{array}{c}\text { Business } \\
\text { Environment }\end{array}\end{array}$} & $\begin{array}{c}\text { Extremely important / } \\
\text { Very Important }\end{array}$ & \multicolumn{3}{c}{$\begin{array}{c}\text { Little important / } \\
\text { Without importance }\end{array}$} \\
\cline { 2 - 7 } & $\begin{array}{c}\text { General } \\
\mathbf{n} \\
(\%)\end{array}$ & $\begin{array}{c}\text { Evaluatio } \\
\mathbf{n} \\
\text { EPMP } \\
(\%)\end{array}$ & $\begin{array}{c}\text { Evaluati } \\
\text { on } \\
\text { GE } \\
(\%)\end{array}$ & $\begin{array}{c}\text { General } \\
\text { Evaluati } \\
\text { on } \\
(\%)\end{array}$ & $\begin{array}{c}\text { Evaluati } \\
\text { on } \\
\text { EPMP } \\
(\%)\end{array}$ & $\begin{array}{c}\text { Evaluati } \\
\text { on } \\
\text { GE } \\
(\%)\end{array}$ \\
\hline Customers & $\mathbf{9 2 . 4}$ & 97.0 & 89.0 & - & - & - \\
Economic & $\mathbf{7 6 . 4}$ & 65.0 & 86.0 & $\mathbf{5 . 4}$ & 7.0 & 4.0 \\
$\begin{array}{l}\text { Technology and } \\
\text { Innovation }\end{array}$ & $\mathbf{7 4 . 0}$ & 68.0 & 79.0 & $\mathbf{6 . 1}$ & 12.0 & 1.0 \\
Competition & $\mathbf{7 1 . 8}$ & 68.0 & 75.0 & $\mathbf{1 0 . 7}$ & 10.0 & 11.0 \\
Political-Regulatory & $\mathbf{7 1 . 0}$ & 62.0 & 79.0 & $\mathbf{5 . 4}$ & 7.0 & 4.0 \\
$\begin{array}{l}\text { Sociocultural and } \\
\text { Demographic }\end{array}$ & $\mathbf{4 8 . 9}$ & 47.0 & 51.0 & $\mathbf{1 3 . 8}$ & 20.0 & 8.0 \\
\hline
\end{tabular}

Source: Survey Data (2017).

Table 2 shows the mean of ratings of owners and/or managers of groups of EPMP, GE, and the general assessment, concerning the degree of importance of the constituent sectors of their business environments. 
Table 2 - Averages of Degree of importance - Sectors of the Business Environment

\begin{tabular}{lc|c|c}
\hline \multicolumn{1}{c|}{$\begin{array}{c}\text { Sectors of the } \\
\text { Business Environment }\end{array}$} & $\begin{array}{c}\text { General } \\
\text { Evaluation }\end{array}$ & $\begin{array}{c}\text { EPMP } \\
\text { Evaluation }\end{array}$ & GE Evaluation \\
\hline Customers & 4.69 & 4.78 & 4.62 \\
Economic & 4.15 & 3.88 & 4.37 \\
Technology and Innovation & 4.03 & 3.87 & 4.17 \\
Competition & 3.94 & 3.92 & 3.96 \\
Political-Regulatory & 4.02 & 3.78 & 4.23 \\
Sociocultural and Demographic & 3.53 & 3.43 & 3.61 \\
\hline
\end{tabular}

Source: Survey Data (2017).

The sector customers was considered 'extremely important/very important' by $92.4 \%$ of the entrepreneurs and/or managers interviewed, obtaining an average score of 4.69 . This index was $97 \%$ (evaluations 'extremely important/Very Important') in the EPMP (with an average of 4.78), while in the GE was $89 \%$ (evaluations 'extremely important/Very Important' and an average grade of 4.62). Given its importance, this sector has not obtained scores of type 'little importance/unimportant', nor in the overall evaluation, nor in the evaluation by size of companies.

The economic sector was in 2nd place as 'extremely important/Very Important', with a general assessment of $76.4 \%$, and an average of 4.15 . Such classification is confirmed in the evaluation of GE, where it was obtained the index of $86.0 \%$ (ratings 'extremely important/Very Important' and an average grade of 4.37), and almost 10 percentage points above the general assessment. However, this sector is assessed as 'extremely important/very important' by $65.0 \%$ of the EPMP (and an average grade of 3.88), more than 10 percentage points below the overall evaluation, and with a difference of 21 percentage points in relation to the GE evaluation. With this, for the EPMP, it ended up setting as the 4th in degree of importance, behind the Technology and Innovation Sectors and Competition. As to the classifications of type 'little importance/unimportant', the economic sector obtained general evaluation of $5.4 \%$, $7.0 \%$ by the EPMP, and $5.4 \%$ by GE.

The Technology and Innovation Sectors, Competition and political-Regulatory obtained general assessments of type 'extremely important/very important' very close (74.0\%, $71.8 \%$ and $71.0 \%$, respectively). In the EPMP, these percentages were below the general assessments $(68.0 \%, 68.0 \%$ and $62.0 \%$, respectively), while in the GE, the percentages were above the general assessments $(79.0 \%, 75.0 \%$ and $79.0 \%$, respectively).

It is interesting to observe the competition sector, as the ratings of type 'little importance/unimportant': this sector was in 2nd place in this type of classification, with average rating of $10.7 \%$. For the EPMP, this index was $10.0 \%$, and for GE, $11.0 \%$. Regardless of the size, such indexes show that this important sector deserves to be seen with more attention by organizations, given the intensification of the dispute of the market and the threat of loss, among the participating companies, competitive 
advantages and even customers, if they do not adequately monitor their competitors (not only local but global).

The Sociocultural and demographic sector was in 6th place, in degree of importance, with a general assessment of $48.9 \%$ in evaluations 'extremely important/Very Important', and an average grade of 3.53. This sector was also the lowest assessment, compared to other sectors analyzed, both by the EPMP $(47.0 \%)$, as well as by GE (51.0\%).

Comparing the results obtained with the work of Barbosa (2002) and Mafra Pereira (2006), we have that : (i) the sector customers, considered the most important by owners/managers interviewed, also appears in 1st place in the studies of Barbosa (2002) and of Mafra Pereira (2006); (ii) the technology and innovation sector appears in 3rd place in this work, as well as in the studies by Barbosa (2002); already at work of Mafra Pereira (2006), this sector appears as the 2nd most important; (iii) the sociocultural and demographic sector presents similar results to the other: is unanimous in its placement as the least important, getting in 6th place, compared to other sectors surveyed; iv) the economic sector, That this work appears in 2nd place, presents differences with relation to the results obtained by other authors: in Mafra Pereira (2006), it is considered the third most important, and in the work of Barbosa (2002), appears as the 5th most important, ahead only of sociocultural and demographic sector ; (v) the sector competition, which in this work appears in 4th place, obtained in the same position in the work of Barbosa (2002); in Mafra Pereira (2006), this sector appeared in 5th place.

\subsection{Perception regarding the change rate of sectors of the business environment}

Table 3 presents the perception of owners and/or managers of groups of EPMP and GE when the degree of importance of the constituent sectors of their business environments, with emphasis on the sum percentage of the conditions 'extremely high change' and 'high change', on the one hand, and 'little important' and 'without importance', on the other hand. 
Table 3 - Change Rate - Sectors of the Business Environment

\begin{tabular}{|c|c|c|c|c|c|c|}
\hline \multirow{2}{*}{$\begin{array}{l}\text { Sectors of the } \\
\text { Business } \\
\text { Environment }\end{array}$} & \multicolumn{3}{|c|}{$\begin{array}{c}\text { Very high change / } \\
\text { High Change }\end{array}$} & \multicolumn{3}{|c|}{$\begin{array}{c}\text { Low change/ } \\
\text { Very low change }\end{array}$} \\
\hline & $\begin{array}{c}\text { Evaluatio } \\
\text { n } \\
(\%)\end{array}$ & $\begin{array}{c}\text { Evaluatio } \\
\text { n } \\
\text { EPMP } \\
(\%) \\
\end{array}$ & $\begin{array}{c}\text { Evaluati } \\
\text { on } \\
\text { GE } \\
(\%) \\
\end{array}$ & $\begin{array}{c}\text { Evaluati } \\
\text { on } \\
(\%)\end{array}$ & $\begin{array}{c}\text { Evaluati } \\
\text { on } \\
\text { EPMP } \\
(\%)\end{array}$ & $\begin{array}{c}\text { Evaluati } \\
\text { on } \\
\text { GE } \\
(\%) \\
\end{array}$ \\
\hline Economic & 65.7 & 62.0 & 69.0 & 12.2 & 20.0 & 6.0 \\
\hline $\begin{array}{l}\text { Technology and } \\
\text { Innovation }\end{array}$ & 57.3 & 56.0 & 56.0 & 16.8 & 18.0 & 15.0 \\
\hline Customers & 39.0 & 42.0 & 37.0 & 25.2 & 17.0 & 32.0 \\
\hline Competition & 35.2 & 38.0 & 31.0 & 30.5 & 30.0 & 32.0 \\
\hline Political-Regulatory & 32.1 & 27.0 & 37.0 & 30.5 & 37.0 & 18.0 \\
\hline $\begin{array}{l}\text { Sociocultural and } \\
\text { Demographic }\end{array}$ & 26.7 & 25.0 & 28.0 & 35.9 & 37.0 & 35.0 \\
\hline
\end{tabular}

Source: Survey Data (2017).

Table 4 shows the mean of ratings of owners and/or managers of groups of EPMP, GE, and the general assessment, concerning the change rate of the constituent sectors of their business environments.

Table 4 - Averages of Change Rate - Sectors of the Business Environment

\begin{tabular}{l|c|c|c}
\hline \multicolumn{1}{c|}{$\begin{array}{c}\text { Sectors of the } \\
\text { Business Environment }\end{array}$} & $\begin{array}{c}\text { General } \\
\text { Evaluation }\end{array}$ & $\begin{array}{c}\text { EPMP } \\
\text { Evaluation }\end{array}$ & GE Evaluation \\
\hline Economic & 3.73 & 3.62 & 3.82 \\
Technology and Innovation & 3.63 & 3.62 & 3.65 \\
Customers & 3.20 & 3.35 & 3.07 \\
Competition & 3.02 & 2.98 & 3.04 \\
Political-Regulatory & 2.99 & 2.77 & 3.18 \\
Sociocultural and Demographic & 2.82 & 2.78 & 2.86 \\
\hline
\end{tabular}

Source: Survey Data (2017).

The economic sector is what has the highest rate of change, according to the perception of the owners and/or managers participants: percentage of $65.7 \%$ obtained by adding up the conditions 'very high/high change' (an average grade of 3.73), while in the EPMP this index was 62.0\%, and 69.0\% of GE, (averages of 3.62 and 3.82 , respectively). The Technology and Innovation sector was in 2 nd place regarding the perception of the interviewees about the rate of change, with a percentage of $57.3 \%$ of general assessment considering the conditions 'very high/high change' (and an 
average grade of 3.63 ), $56.0 \%$ in the EPMP (an average of 3.62 ) and $56.0 \%$ in GE (an average of 3.65). The sectors Customers, Competition and political-Regulatory obtained general assessments regarding the conditions 've4ry high /high' change of $39.0 \%, 35.2 \%$ and $32.1 \%$, respectively. In the EPMP, the percentage of customers and competition sectors remained above the general assessment (42.0\% and $38.0 \%)$, while in the GE, was the political sector-Regulatory that obtained percentage points above the general assessment (37.0\%).

It is interesting to note, in particular, the indexes obtained by customers and Competition. Concerning the Customers sector, although considered as the most important in the perception of the participating undertakings, it is the 3rd in rate of change, with almost 20 percentage points below the 2 nd one. In addition, $25.2 \%$ of the general views believe that this sector has low rate of change or very low. Comparing such results, it is perceived that the participating companies, even considering the sector as the most important to their business, in practice do not consider it as a dynamic sector, perhaps because they do not neglect it in a systematic way and, therefore, do not understand the intense changes that have occurred in recent years in the behavior and in consumer markets of Brazilian companies. Anyhow, this perception needs to be confirmed by other studies.

The sector competition, considered as the 2nd 'little importance/unimportant', also presented perceptions on the part of the respondents, which is a sector with 'low/very low change' (in the overall evaluation, this index was $30.5 \%$, and $30.0 \%$ in the EPMP and $32.0 \%$ in GE). These indices, to a certain extent, help to define the analysis pointed out earlier that companies, in general, are not aware, as they should be, of the movements of competitors in their business environment, an aspect which ends up setting up a possible situation of low utilization (or even the absence) of market monitoring processes and/or IC on the part of these companies.

The Sociocultural and demographic sector was in 6th place, in change rate, with a general assessment of $26.7 \%$ in evaluations 'very high/high change', and an average grade of 2.82. This sector was also the lowest assessment, compared to other sectors analyzed, both by the EPMP $(25.0 \%)$, as well as by GE $(28.0 \%)$.

Comparing the results obtained with the work of Barbosa (2002) and Mafra Pereira (2006), we have found that: i) the economic sector, considered with the highest rate of change by owners/managers interviewed, appears in 2 nd place in the studies of Barbosa (2002) and of Mafra Pereira (2006); (ii) the technology and innovation sector appears in 2nd place in this work, whereas in studies of Barbosa (2002) and of Mafra Pereira (2006), appears in 1st with a higher rate of change; (iii) the sociocultural and demographic sector presents similar results to the others: it is unanimous in its placement as the lowest rate of change, ending in 6th place, compared to other sectors surveyed; iv) the Customer sector appears in this work with the 3rd in rate of change, while at work to Barbosa (2002) is the 4th, and of Mafra Pereira (2006), the 5th; (v) the Competition sector, which in this work appears in 4th place, is the 3rd in Mafra Pereira (2006), the same position obtained in the work of Barbosa (2002). 
Figure 4 - Comparative Relationship between the degree of importance and rate of change of the sectors of the Business Environment - general assessment.

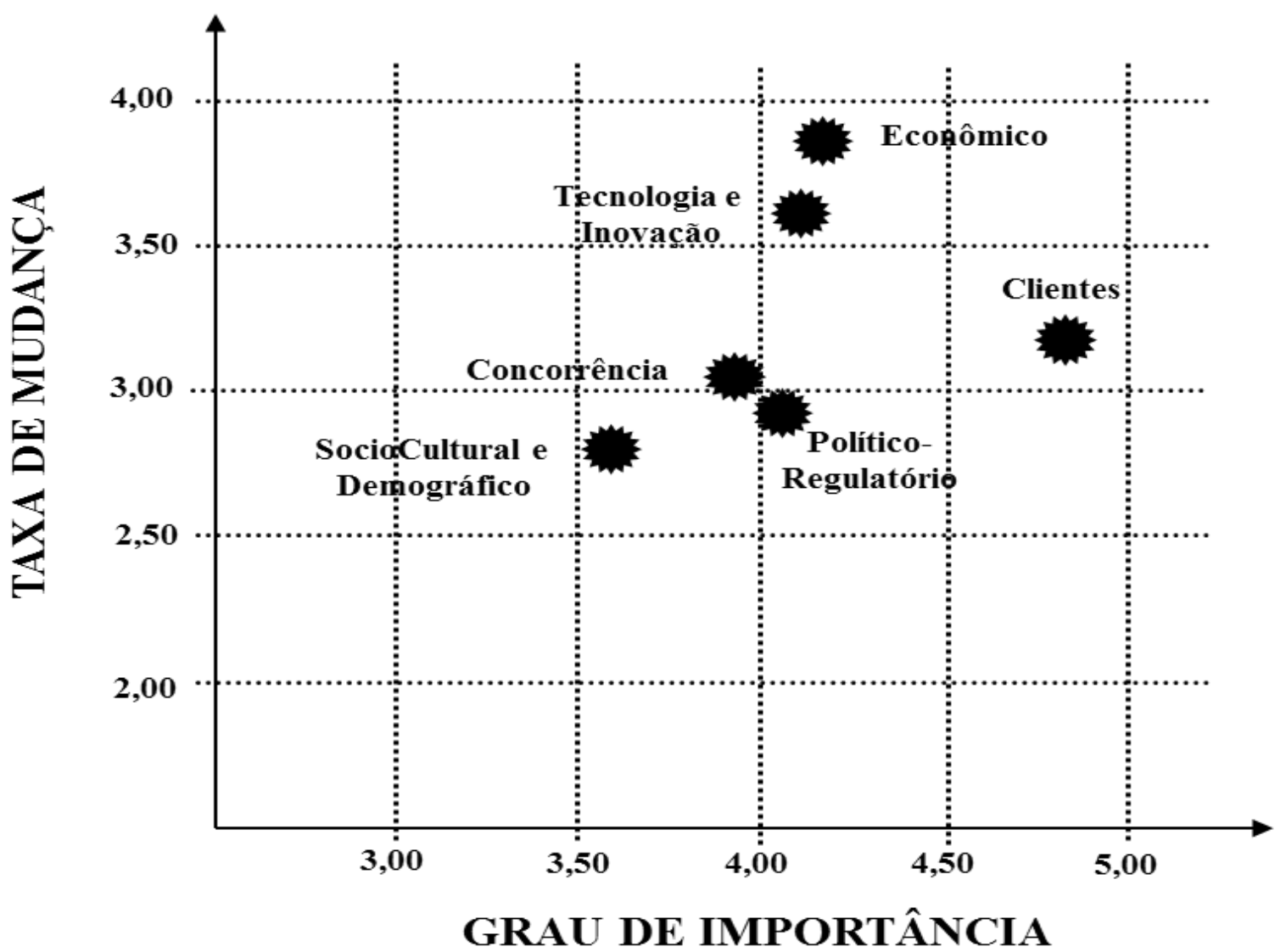

Source: Prepared by the author (2017).

\subsection{Main Uses given to information gathered in the business environment}

In this item, the main uses were identified given by the owners and/or managers interviewed to information collected in the business environment of their companies, based on strategic 'arenas' of Choo (2006). The data indicate that the 'main objective/first purpose' for the use of the collected information is to search for information to inform the decision-making process. In the overall evaluation, this strategic arena obtained $42.7 \%$ of opinions indicating to be the 'main objective/first purpose' use. For the EPMP, this arena obtained $35.0 \%$ of opinions indicating that the main objective/first purpose' of use, while for the GE, this index was $49.0 \%$. 
Table 5 - Main strategic arenas for the use of the information - General assessment

\begin{tabular}{|c|c|c|c|c|c|}
\hline Purposes of information use & $\begin{array}{c}\text { Main } \\
\text { objective }\end{array}$ & $\begin{array}{l}\text { Second } \\
\text { Objective }\end{array}$ & $\begin{array}{l}\text { Third } \\
\text { Objective }\end{array}$ & NS/NR & TOTAL \\
\hline $\begin{array}{l}\text { Seek information to make } \\
\text { decisions }\end{array}$ & $42.7 \%$ & $23.7 \%$ & $26.0 \%$ & $7.6 \%$ & $100.0 \%$ \\
\hline $\begin{array}{l}\text { Follow and understand the } \\
\text { business environment }\end{array}$ & $26.0 \%$ & $46.6 \%$ & $19.1 \%$ & $8.4 \%$ & $100.0 \%$ \\
\hline $\begin{array}{l}\text { Generate and build new } \\
\text { knowledge }\end{array}$ & $24.4 \%$ & $21.4 \%$ & $46.6 \%$ & $7.6 \%$ & $100.0 \%$ \\
\hline TOTAL & $100.0 \%$ & $100.0 \%$ & $100.0 \%$ & & - \\
\hline
\end{tabular}

Source: Survey Data (2017).

As a second objective/purpose, it was identified the strategic arena follow and understand the business environment (46.6\% in the overall assessment). For the EPMP, this arena obtained $33.0 \%$ of opinions indicating to be the'second objective/ purpose' of use, while for the GE, this index was $58.0 \%$. Thirdly, it was identified the strategic arena to generate and build new knowledge $(46.6 \%$ in the overall assessment). For the EPMP, this arena obtained $37.0 \%$ of opinions indicating to be the 'third objective/ purpose' of use, while for the GE, this index was $55.0 \%$.

Based on these results, it can be seen that the use of the information with a focus on three strategic arenas of Choo (2006) is more intense in the GE, compared to EPMP. In other words, the purposes are clearer given to the information resulting from the business environment by GE, (see the indices of statements of these companies, higher than the overall assessment). On the other hand, in the EPMP, such uses are more diluted among the types of strategic arenas, which may suggest a certain lack of focus on the use made of the information resulting from the business environment, considering, also, the possibility of these companies do not realize, in fact, any activity of market monitoring or IC; i.e., in the case of not performing such processes, are even more undecided as to what will be done in the future, compromising even the definition of effective business strategies.

It is important to note that all of these observations with respect to the main purposes of use of information by entrepreneurs and managers interviewed are based on quantitative data collected by the survey. However, they should also be researched in depth, along with this public (via qualitative and/or exploratory research), as already highlighted and recommended earlier in this same analysis.

\section{Final Considerations}

The results obtained in this allowed to fulfill the main objective to evaluate the perception of entrepreneurs and business managers of micro, small, medium and large sizes, located in Belo Horizonte (MG), on the degree of importance and the rate of change of the sectors/components of their business environment, and the main uses given to the information collected in this environment. In specific terms, it was possible 
to identify the degree of importance that the interviewees of EPMP and GE give constituent sectors of their respective business environments, as well as the perception that have as to the rate of change (dynamic) of these sectors, with special attention to the Customers, economical and technology and innovation sectors. It was also possible to identify the main uses given to information arising out of their respective business environments, with emphasis on the search for information with a view to assist the decision-making processes.

In addition to these contributions, it was also possible to test the 'Analytical Theoretical Model: Information for use and definition of business strategies via monitoring of the Business Environment and Competitive Intelligence', proposed and used as a structure for the elaboration of the instrument of data collection and analysis of data collected in this survey.

Regarding he limitations of this study, it is noteworthy that the results presented correspond exclusively to the perceptions of entrepreneurs and managers of companies located in Belo Horizonte (MG), a market which can provide specifics, as compared to the others. Another limitation lies in the fact that the results presented, by reason of the limited sample, have not been validated by means of advanced statistical tests.

Thus, it is recommended that, for future work, the application of the proposed model, as well as of the aspects investigated, in other organizational contexts, so as to contribute to the expansion of theoretical and applied on the topics covered in this study.

Finally, the work presented justified its importance and relevance to the fields of Administration and Information Science, contributing with a study of the perception of entrepreneurs and managers about their business environments, on monitoring of the market and HF, as well as on the strategic use of information aimed at the effective preparation of business strategies.

\section{References}

AGUILAR, F.J. Scanning the business environment. New York: The Macmillan Company, 1967.

ALBANO, C.S.; ARAÚJO, M.H. Inteligência competitiva e monitoramento ambiental utilizando informações disponíveis na internet: a viabilidade de utilizar dados governamentais abertos. Anais do Encontro de Administração da Informação (IV EnADI), Bento Gonçalves, RS, Brasil, 2013.

ALDRICH, H.E. Organizations and environments. Englewood Cliffs, New Jersey: Prentice-Hall, 1979.

ANSOFF, H.I.; McDONNELL, E.J. A Administração Estratégica. 2a ed. São Paulo: Atlas, 1993.

AUSTER, E.; CHOO, C.W. How senior managers acquire and use information in environmental scanning. Information Processing and Management, v.30. n.5, p.607-618, 1994. 
BARBALHO, C.R.S.; VALENTIM, M.L.P.; HOFFMANN, W.A.M. Uso da inteligência competitiva em empresas brasileiras de produtos naturais. Anais do Encontro Nacional de Pesquisa e Pós-Graduação em Ciência da Informação (VIII ENANCIB), Salvador, BA, Brasil, 2007.

BARBOSA, R.R. Gestão da Informação e do Conhecimento: origens, polêmicas e perspectivas. Informação \& Informação, v.13, Edição Especial, p.1-25, 2008.

BARBOSA, R.R. Inteligência empresarial: uma avaliação de fontes de informação sobre o ambiente organizacional externo. DataGramaZero - Revista de Ciência da Informação, v.3. n.6, dez., 2002.

BARBOSA, R.R. Monitoração ambiental: uma visão interdisciplinar. Revista de Administração, v.32, n.4, p.42-53, out./dez., 1997.

BARBOSA, R.R. Uso de fontes de informação para a Inteligência Competitiva: um estudo da influência do porte das empresas sobre o comportamento informacional. Encontros Bibli: Revista Eletrônica de Biblioteconomia e Ciência da Informação, n. esp., p.91-102, 1ํsem., 2006.

BARNEY, J.B.; HESTERLY, W.S. Administração estratégica e vantagem competitiva. São Paulo: Pearson Prentice Hall, 2007.

BORTOLUZZI, F.R.; DA SILVA, E.R.; SACILOTO, E.B.; FACHINELLI, A.C. Inteligência Estratégica e Análise: revisão sistemática da literatura. Revista Inteligência Competitiva, v.4, n.3, p.27-38, abr./jul., 2014.

BURNS, T.; STALKER, G.M. The management of innovation. London: Tavistock, 1961.

BUZZERIO, F.G.; MARCONDES, R.C. A Inteligência Competitiva na perspectiva de ser uma fonte de vantagem competitiva e suas contribuições estratégicas. Revista de Ciências da Administração, v.16, n.40, p.235-249, dez., 2014.

CANONGIA, C.; LAMB, C.; CARVALHO, C.S.de P.; VALDENIS, S. S. Convergência da IC com construção de visão de futuro: proposta metodológica de sistema de informação estratégica (SIE). DataGramaZero - Revista de Ciência da Informação, v.2, n.3, jun., 2001.

CERVO, A.L.; BERVIAN, P.A.; DA SILVA, R. Metodologia Científica. 6a ed. São Paulo: Pearson Prentice Hall, 2009.

$\mathrm{CHOO}, \mathrm{C} . \mathrm{W}$. The knowing organization: how organizations use information to construct meaning, create knowledge, and make decisions. 2a ed. New York: Oxford University Press, 2006.

CRESWELL, J.W. Research design: qualitative, quantitative, and mixed methods approaches. 2a ed. Thousand Oaks: Sage, 1994.

CYERT, R.M.; MARCH, J.G. A behavioral theory of the firm. Englewood Cliffs, New Jersey: Prentice-Hall, 1963.

DAFT, R.L.; SORMUNE, J.; PARKS, D. Chief executive scanning, environmental characteristics, and company performance: an empirical study. Strategic Management Journal, v.9, n.2, p.123-139, 1988. 
DAVENPORT, T.H.; PRUSAK, L. Conhecimento Empresarial: como as organizações gerenciam seu capital intelectual. Rio de Janeiro: Campus, 1998.

DEGENT, R.J. A importância estratégica e o funcionamento do serviço de inteligência empresarial. Revista de Administração de Empresas, v.26, n.1, p.77-83, jan/mar., 1986.

DILL, W.R. Environment as an influence on managerial autonomy, Administrative Science Quarterly, v.2, n.4, p.409-443, Mar., 1958.

DUNCAN, R.B. Characteristics of organizational environments and perceived environmental uncertainty. Administrative Science Quartely, v.17, n.3, p.313-327, sep., 1972.

FILARDI, F.; SANTOS, S.A.; OLIVA, F.L.; GRISI, C.C.H.; LIMA, A.C. Análise quantitativa sobre a mortalidade precoce de micro e pequenas empresas da cidade de São Paulo. Revista Gestão e Produção, v.19, n.4, p.811-823, 2012.

FREMONT, K. Scanning the future environment: social indicators. California Management Review, v.23, n.1, p.22-32, Fall, 1980.

GOMES, E.; BRAGA, F. Inteligência Competitiva: como transformar informação em um negócio lucrativo. 2ª ed. Rio de Janeiro: Elsevier, 2004.

HARRISON, J.S. Administração Estratégica de recursos e relacionamentos. Porto Alegre: Bookman, 2002.

HERRING, J.P. Create an Intelligence Program for current and future business needs. Competitive Intelligence Magazine, v.8, n.5, p.20-27, Sep-Oct., 2005.

HERRING, J.P. Key Intelligence Topics: A Process to Identify and Define Intelligence Needs. Competitive Intelligence Review, v.10, n.2, p.4-14, 1999.

HOFFMANN, W.A.M. Monitoramento da informação e inteligência competitiva: realidade organizacional. Revista de Ciência da Informação e Documentação, v.2, n.2, p.125-144, 2011.

KATZ, D.; KAHN, R.L. The social psychology of organizations. 2 ed. New York: John Wiley \& Sons, 1978.

LAWRENCE, P.R.; LORSCH, J.W. Organization and environment: managing differentiation and integration. Boston, MA: Harvard University Press, 1967.

LODI, C.F.G. Planejamento por Cenários e Inteligência Competitiva: integrando seus processos para tomar decisões estratégicas mais eficazes. In: STAREC, C.; GOMES, E.; CHAVES, J.B.L. (Orgs.). Gestão Estratégia da Informação e Inteligência Competitiva. São Paulo: Saraiva, p.111-123, 2006.

MAFRA PEREIRA, F.C. Uso de fontes de informação: um estudo em micro e pequenas empresas de consultoria de Belo Horizonte. 2006. 154f. Dissertação (Mestrado em Ciência da Informação). Escola de Ciência da Informação, UFMG, Belo Horizonte, 2006. 
MAFRA PEREIRA, F.C. Fontes de Informação para Negócios: análise sobre frequência, relevância e confiabilidade, baseada em estudo empírico com empresários e gestores organizacionais. Perspectivas em Ciência da Informação, v.21, n.2, p.100119, abr./jun., 2016.

MAFRA PEREIRA, F.C.; BARBOSA, R.R. A decisão estratégica por executivos de micro e pequenas empresas e a cadeia alimentar informacional como modelo integrativo de fontes de informação. In: Anais do Encontro Nacional de Pesquisa em Ciência da Informação, X ENANCIB, João Pessoa: UFPB, p.1113-1131, 2009.

MAFRA PEREIRA, F.C.; SANTOS, M.G.A. Inteligência Competitiva na Indústria Alimentícia: práticas adotadas e proposta de estruturação da IC em uma empresa de processamento mínimo de frutas e hortaliças de Minas Gerais. Revista Inteligência Competitiva, v.5, n.4, p.1-28, set./dez., 2015.

MAFRA PEREIRA, F.C.; CARVALHO, R.B.; JORDÃO, R.V.D. Análise do Ciclo de Inteligência Competitiva em Arranjos Produtivos Locais: estruturação e implantação do bureau de inteligência do APL de software de Belo Horizonte. Revista Inteligência Competitiva, v.6, n.1, p.139-164, jan./mar., 2016.

MAFRA PEREIRA, F.C.; JEUNON, E.E.; BARBOSA, R.S.; DUARTE, L.C. Inteligência Competitiva como suporte à Estratégia Empresarial em micro e pequenas empresas: um estudo na Aerotrópole de Belo Horizonte. Revista Iberoamericana de Estratégia, v.17, p.93-111, 2018.

MALHOTRA, N.K. Pesquisa de Marketing: uma orientação aplicada. 3ª edição. Porto Alegre: Bookman, 2001.

MARTINS, E.L.C. Monitoramento informacional do ambiente de negócios na micro e pequena empresa (MPE): estudo do comércio varejista de materiais para a construção de Cuiabá-MT. Tese de Doutorado, Universidade de Brasília, Brasília, DF, Brasil, 2011.

MILLER, J. O Milênio da inteligência competitiva. Porto Alegre: Bookman, 2002.

MINTZBERG, H. Ascensão e queda do Planejamento Estratégico. Porto Alegre: Bookman, 2007.

MINTZBERG, H. Crafting strategy. Harvard Business Review, v.65, n.4, p.66-75, 1987.

NONAKA, I.; TAKEUCHI, $H$. Criação de conhecimento na empresa: como as empresas japonesas geram a dinâmica da inovação. Rio de Janeiro: Campus, 2008.

OLIVEIRA, D.P.R. Manual de Consultoria Empresarial: conceitos, metodologia, práticas. 19ª edição. São Paulo: Atlas, 2003.

OLIVEIRA, P.H.; TELES, E.L. Relações de dependência informacional entre os processos de administração estratégica e de inteligência competitiva. Revista Inteligência Competitiva, v.5, n.2, p.17-39, abr./jun. 2015.

OLIVEIRA, P.H..; SADE, W. Inteligência Competitiva no contexto das empresas mineiras de artefatos de estanho. Perspectivas em Ciência da Informação, v.21, n.1, p.23-41, jan./mar., 2016. 
PINHEIRO, J.I.D.; CUNHA, S.B.; CARVAJAL, S.R.; GOMES, G.C. Estatística Básica: a arte de trabalhar com dados. Rio de Janeiro: Elsevier, 2009.

PORTER, M.E. Estratégia competitiva: técnicas para análise de indústrias e da concorrência. 7aㅡ ed. Rio de Janeiro: Campus, 1996.

ROCHA JÚNIOR, E.A.; GUIMARÃES, E.H.R.; JEUNON, E.E. Gestão do Conhecimento em Agência de Fomento à Pesquisa: Proposição de um Modelo Aplicado. Revista Gestão \& Tecnologia, v.14, n.3, p.244-260, 2014.

ROMAN, D.J.; PIANA, J.; PEREIRA, M.A.S.; LOZANO, L.; MELLO, N.R.; ERDMANN, R.H. Fatores de competitividade organizacional. BBR - Brazilian Business Review, v.9, n.1, p.27-46, 2012.

SAMARA, B.S.; BARROS, J.C. Pesquisa de Marketing - Conceitos e Metodologia. 3aㅡ edição. São Paulo: Prentice Hall, 2002.

SANTOS, L.L.S.; ALVES, R.C.; ALMEIDA, K.N.T. Formação de Estratégia nas Micro e Pequenas empresas: um estudo no Centro-oeste Mineiro. Revista de Administração de Empresas (ERA), p.59-73, out-dez, 2007.

SCHREIBER, D.; BESSI, V.G.; PUFFAL, D.P.; TONDOLO, V.A.G. Posicionamento estratégico de MPE'S com base na inovação através do modelo Hélice Tríplice. REAd. Revista Eletrônica de Administração, v.19, n.3, p.767-795, 2013.

SEBRAE. Serviço de Apoio às Micro e Pequenas Empresas. Disponível em: <http://www.sebrae.com.br/sites/PortalSebrae/>. Acesso em: 25 jul. 2015.

SILVA, C.J. Gestão de Riscos e Inteligência Competitiva. In: STAREC, C. (Ed.). Gestão da Informação, Inovação e Inteligência Competitiva: como transformar a informação em vantagem competitiva nas organizações. São Paulo: Saraiva, 2012.

SILVA, S.D.; COSTA, F.J. Mensuração e Escalas de Verificação: uma Análise Comparativa das Escalas de Likert e Phrase Completion. PMKT - Revista Brasileira de Pesquisas de Marketing, Opinião e Mídia, v.15, p.1-16, out., 2014.

TEIXEIRA, D.R. As Faces da Inteligência Competitiva: como direcionar a sua organização e definir o perfil profissional. Recuperado em 17 agosto 2017, de http://www.mbi.com.br/mbi/biblioteca/artigos/200704facesintelig/, 2007.

TEIXEIRA, T.M.C.; VALENTIM, M.L.P. Inteligência Competitiva Organizacional: um estudo teórico. Perspectivas em Gestão \& Conhecimento, v.6, Número Especial, p.315, jan., 2016.

TYSON, K.W.M. Competitor Intelligence Manual and Guide. Englewood Cliffs: Prentice-Hall, 1990.

VALENTIM, M.L.P.; CERVANTES, B.M.N. O processo de Inteligência Competitiva em Organizações. DataGramaZero - Revista de Ciência da Informação, v.4, n.3, jun., 2003.

WILSON, T.D. Information Behavior: an interdisciplinary perspective. Information Processing \& Management, v.33, n.4, p.551-572, 1997. 